УДК 614.378(432)

\title{
ПІСЛЯДИПЛОМНА ОСВІТА ЛІКАРІВ В АВСТРІї
}

Г. І. Кліщ

ДВНЗ “Тернопільський держсавний медичний університет імені І. Я. Горбачевського МОЗ України”

\section{POST-GRADUATE EDUCATION OF DOCTORS IN AUSTRIA}

\author{
H. I. Klishch \\ SHEI “Ternopil State Medical University by I. Ya. Horbachevsky of MPH of Ukraine”
}

\begin{abstract}
У статті проаналізовано особливості післядипломного навчання лікарів в Австрії. Наведено цілі і завдання післядипломного навчання, напрями підготовки, а також їі особливості в Австрії. Особлива увага приділяється питанням ліцензування навчальних баз для післядипломного навчання лікарів, а також надання дозволу на можливість керівництва лікарями-інтернами.
\end{abstract}

The article adduces the features of post-graduate education of doctors in Austria. The goals and objectives of post-graduate education, its features and training areas in Austria are analyzed. Particular attention is paid to the licensing of training bases for post-graduate education, as well as to the licensing of teachers for the direction by interns.

Вступ. Особливістю підготовки лікарів в Австрії, як і в інших країнах Свропи, $є$ необхідність після отримання базової медичної освіти і наявності диплома 3 медицини пройти первинну спеціалізацію із певного розділу медицини з метою отримання сертифіката спеціаліста. Цілі спеціалізації такі: здобуття глибоких знань, досвіду та вмінь, необхідних для здійснення прямої чи опосередкованої диференційованої лікарської діяльності дипломованими лікарями після завершення ними професійного навчання, відповідно до вказаного обсягу знань, зазначеного в дипломі. Метою спеціалізації є забезпечення високої якості роботи медичного працівника.

Основна частина. Завершальною і обов'язковою формою підготовки випускників вищих медичних навчальних закладів Австрії $є$ інтернатура. Особливістю організації післядипломної підготовки лікарів в Австрії $є$ те, що вона належить до компетенції Асоціації лікарів Австрії (Osterreichische Arztekammer), зокрема ії підрозділу - Австрійської академії лікарів (Osterreichischen Akademie der Arzte), а навчальні заклади не беруть безпосередньої участі у післядипломному навчанні [1].

Післядипломне навчання здійснюється у двох напрямках:

1) для отримання фаху лікаря загальної практики (сімейного лікаря);

2 для отримання фаху вузького спеціаліста [2 ].

Для отримання сертифіката лікаря загальної практики (Arzt fur Allgemeinmedizin) випускник медично- го університету, відповідно до §7 “Закону про лікарів” (Arztegesetz), має протягом трьох років пройти підготовку в інтернатурі у статусі лікаря-стажиста (Turnusarzt) і скласти іспит з оволодіння професією, що передбачено §26 цього ж закону. Навчання відбувається за цикловою системою і включає такі предмети, як: загальна медицина (6 місяців), хірургія (4 місяці), акушерство і гінекологія (4 місяці), оториноларингологія (2 місяці), дерматологія (2 місяці), внутрішня медицина (12 місяців), педіатрія (4 місяці), неврологія/психіатрія (2 місяці). Інтерни виконують таку ж роботу, як і штатні лікарі, однак не несуть юридичної відповідальності за ії наслідки. Під час навчання вони пишуть розширену історію хвороби з літературним оглядом на зразок магістерської роботи, успішний захист якої є обов'язковою умовою допуску до складання ліцензійного тестового іспиту [3 ]. Після успішного складання іспиту інтерн отримує практичний медичний диплом (“Ius Practicandi”). Тільки сертифікований спеціаліст має право на здійснення медичної практики [4 ].

Якщо ж у подальшому лікар загальної практики захоче отримати сертифікат вузького спеціаліста (Facharzt) - наприклад хірурга, уролога, офтальмолога, дерматовенеролога тощо, він має додатково стажуватися за обраним фахом протягом 3-х років (§ 8 “Закону про лікарів”) і також, у разі повного виконання програми навчання і досягнення необхідних кваліфікаційних навичок, скласти іспит для отримання сертифіката. 
Загальні вимоги до спеціалізації:

1) проходити спеціалізацію можна лише після отримання повної вищої освіти за напрямком “Медицина";

2) якщо лікар протягом навчального періоду демонструє діяльність, яка охоплює вимоги певної спеціалізації, то ця діяльність в рамках мінімального часу, необхідного для здобуття спеціалізації, зараховується як така;

3) спеціалізація має бути грунтовною та всебічною. Вона охоплює, в першу чергу, поглиблення знань, умінь та навичок профілактики, виявлення та лікування хвороб, тілесних ушкоджень, а також взаємовідносини між людиною й навколишнім середовищем, експертизу необхідних заходів реабілітації та заходів забезпечення якості медичної діяльності. Спеціалізація служить виключно для поглиблення здобутих під час навчання знань та навичок у межах відповідного фаху. Існують певні особливі межі фаху, через які не можна переступити, здобувши спеціалізацію;

4) тривалість та зміст спеціалізації регулюються відповідними вимогами до порядку здобуття спеціа-
1. Анестезіологія та інтенсивна терапія.
2. Анатомія.
3. Професійні захворювання і медицина підприємств.
4. Офтальмологія і оптометрія.
5. Серологія груп крові і трансфузійна медицина.
6. Хірургія.
7. Гінекологія.
8. Судова медицина.
9. Оториноларингологія.
10. Шкірні та венеричні захворювання.
11. Гістологія та ембріологія.
12. Гігієна і мікробіологія.
13. Імунологія.
14. Внутрішня медицина.
15. Дитяча хірургія.
16. Дитяча і підліткова медицина.
17. Пульмонологія.
18. Медична біологія.
19. Медична біофізика.
20. Медико-хімічна лабораторна діагностика.
21. Репродуктивна медицина.
22. Медична діагностична радіологія.
23. Щелепно-лицева і лицева хірургія.

Після закінчення повного курсу спеціалізації, відповідно до § 14 “Закону про лікарів”, проводиться тестовий іспит. Допуск до іспиту дає керівник інтерна, враховуючи виконання програми спеціалізації, набуті кваліфікаційні знання і навички. Метою проведення іспиту є виявлення необхідних компетенцій, які повинен мати лікар відповідного фаху [7]. Порядок проведення іспиту розроблений Австрійською асоціацією лізації. Термін переривання процесу набуття спеціалізації через хворобу, декретну відпустку, звичайну відпустку може становити 1/6 від загальної тривалості періоду спеціалізації;

5) спеціалізація має бути направлена на здобуття знань, умінь та навичок, що відповідають ії цілям, має відбуватися в межах встановлених дисциплін та мати чітко встановлений обсяг. Рішення про отримання свідоцтва про закінчену спеціалізацію виносить Австрійська медична асоціація, опираючись на отримані документи [5 ].

Цілі спеціалізації такі: здобуття глибоких знань, досвіду та вмінь, необхідних для здійснення прямої чи опосередкованої диференційованої лікарської діяльності дипломованими лікарями після завершення ними професійного навчання, відповідно до вказаного обсягу знань, зазначеного в дипломі. Метою спеціалізації є також забезпечення високої якості роботи медичного працівника [6 ].

Австрійські лікарі-інтерни можуть проходити спеціалізацію з таких напрямів:

24. Нейробіологія.
25. Нейрохірургія.
26. Неврологія.
27. Невропатологія.
28. Ядерна медицина.
29. Ортопедія та ортопедична хірургія.
30. Патологія.
31. Патофізіологія.
32. Фармакологія і токсикологія.
33. Фізична медицина.
34. Фізіологія.
35. Пластична хірургія.
36. Психіатрія.
37. Соціальна медицина.
38. Специфічна профілактика і тропічна медицина.
39. Променева терапія - радіоонкологія.
40. Біологія пухлин.
41. Хірургічна допомога при нещасних випадках (трав-
матологія).
42. Урологія.
43. Вірусологія.
44. Терапевтична стоматологія.

лікарів у 2001 році окремо для лікарів загальної практики і спеціалістів і мав кілька доповнень. На сьогодні актуальним $є$ документ 3 доповненнями 2010 року (Prufungsordnung der Osterreichischen Arztekammer fur die Prufung zum Arzt fur Allgemeinmedizin und die Facharztprufung-PO 2011). У ньому висвітлено перелік умов для допуску до іспиту, порядок його проведення, порядок видачі по- 
свідчення про складений іспит, оформлення можливої апеляції [8].

У разі успішного складання іспиту лікареві, відповідно до § 14 “'Закону про лікарів”, видається сертифікат про спеціалізацію. Оформленням сертифіката займається Австрійська асоціація лікарів, при цьому у сертифікаті поіменно вказано, які види роботи і навички отримав лікар, що закінчив спеціалізацію у відповідний час та у відповідних відділах. Зміст сертифікатів про спеціалізацію укладається відповідно до актуального стану медицини та під впливом міжнародного розвитку відповідних сфер медицини, за рекомендаціями визнаних фахових наукових товариств та відповідних федеративних секцій, у тому числі відповідних федеративних фахових груп [9].

Визнання спеціалізації може бути анульоване, якщо не були дотримані відповідні умови. Рішення про анулювання спеціалізації приймає президент Австрійської асоціації лікарів. Рішення президента може бути оскаржене відповідним рішенням асоціації. У рішенні про анулювання зазначається, які дії має вчинити лікар, щоб повернути собі спеціалізацію [10].

Вимоги до навчальних баз для проведення післядипломного навчання лікарів загальної медицини регулюються $\S 9$ “Закону про лікарів”. Навчальними центрами, відповідно до цього пункту, можуть бути відділення у клінічних лікарнях, клінічні інститути та інші структурні підрозділи, включаючи будь-які підрозділи медичних навчальних закладів, які були визнані Австрійською асоціацією лікарів як база для підготовки лікарів у цій сфері медицини [18]. Що стосується визнання університетських лікарень, клінічних інститутів та інших структурних підрозділів, включаючи будь-які підрозділи австрійських медичних університетів, асоціація повинна домовитися з федеральним міністром освіти, науки та культури для отримання його дозволу на проведення занять 3 лікарями-інтернами. Визнані навчальні бази мають бути включені до реєстру, який ведеться Австрійською асоціацією лікарів (список затверджених навчальних баз для підготовки лікарів в конкретній сфері медицини). Для визнання навчальних центрів для підготовки інтернів 3 анестезіології та інтенсивної терапії як факультативних предметів необхідною умовою є наявність у лікарні хоча б одного фахівця 3 анестезіології та інтенсивної терапії [12 ].

Навчальним центром для здійснення післядипломної медичної освіти у сфері загальної медицини може бути визнаний лише той медичний заклад, який має у своїй структурі відповідні відділи та інші підрозділи, а також можливості для:
1) обстеження і лікування лежачих хворих і їх подальшого спостереження;

2) засвоєння навичок, які необхідні лікарям загальної практики (кілька відділів або частин відділів), які керуються фахівцями відповідних спеціальних дисциплін;

3) забезпечення інтернів необхідною кількістю лікарів різних спеціальностей, які потрібно опанувати лікарю загальної практики, з відповідним досвідом роботи у своїй сфері;

4) забезпечення необхідними технічними засобами та обладнанням, включаючи й ті, що потрібні для викладання і вивчення матеріалу.

Підготовка лікарів загальної практики передбачає засвоєння певних навичок із вузьких спеціальностей. У великих навчальних центрах є усі спеціалізовані відділення, однак не всі земельні лікарні мають ці структурні підрозділи. Проте законом передбачено, що такі лікарні можуть бути визнаними навчальними центрами для медичної освіти у сфері загальної медицини за відсутності відділів або організаційних одиниць захворювань вуха, горла та носа, шкірних і венеричних захворювань, дитячої й підліткової медицини, неврології та психіатрії, за умови, якщо практичне навчання у цих галузях медицини буде здійснюватись кваліфікованими лікарями і медичними працівниками, які принаймні рік працюють у цій лікарні в якості позаштатного консультанта, зберігаючи при цьому робочі відносини з лікарнею, в рамках визнаної професійної медичної практики. У всіх інших випадках, коли лікарні не мають відповідних відділів або підрозділів, вони не визнаються навчальними базами [11].

Керівництво визнаних навчальними базами закладів охорони здоров'я зобов' язане, з урахуванням офіційно відведеного на навчальний період часу, подбати про надання кваліфікованої освіти лікарям-інтернам у навчальних закладах медичного спрямування. Лікарі-інтерни зобов'язані, у свою чергу, старанно навчатися 3 метою оволодіння майбутньою професією лікаря загальної медицини. Вони особисто беруть участь у роботі, та, відповідно до їх рівня підготовки, несуть відповідальність за власні дії. Навчання, що проводиться керівником відділу чи призначеним лікарем (асистентом), як правило, має велику підтримку з боку інших, працюючих у відділенні лікарів, що сприяє набуттю психосоматичної та психосоціальної компетентності, особливо у спілкуванні з пацієнтами [13 ].

Інтернам, беручи до уваги набуті ними компетенції у вищому закладі медичної освіти, дозволено брати 
участь у заходах із підвищення професійної кваліфікації. Лікар-інтерн є важливою частиною медичного персоналу. У такій якості чи ролі він має право давати розпорядження дипломованому медичному персоналу в межах сфери діяльності відповідно до Закону про охорону здоров’я. Спостерігаючи за лікарями, які працюють у лікарні, інтерни перш за все спостерігають за медичною допомогою, яку вони надають, засвоєння азів якої є їх основним завданням. Лікар-інтерн має орієнтувати свої дії відповідно до завдань та стратегічних напрямків керівництва медичного закладу [16].

Обов'язком лікаря-інтерна є якісне та продуктивне виконання покладеної на нього лікарської діяльності. Він має перейняти на себе навіть ту діяльність, яка йому згодом безпосередньо не знадобиться, але $\epsilon$ надзвичайно важливою при наданні медичної допомоги пацієнтам [14].

Всі види діяльності, якими займаються у медичних закладах інтерни, поділяються, в рамках їх діяльнісного профілю, на: первинну (основну) медичну діяльність лікаря-інтерна, делеговану медичну діяльність, та інші види так званої неінтернської діяльності, яку йому можуть доручити. Прикладами первинної лікарської діяльності лікаря-інтерна є участь у стаціонарному лікуванні та повна участь у пов'язаному з пацієнтом процесі прийняття рішень. Сюди належать також обов'язкова участь у візитах/обходах пацієнтів та консиліумах, на яких обговорюється стан хворих (наприклад, обговорення результатів інструментальних чи лабораторних досліджень, рентгенологічних обстежень тощо).

Делегована діяльність інтерна може відбуватися відповідно до розпоряджень головного лікаря чи заступника 3 медичного обслуговування та охорони здоров'я і включає постановку капельниці із розчинами для внутрішньовенного вливання, підшкірні та внутрішньом’язові ін'єкції, встановлення постійних катетерів, введення зонда у шлунок, відсмоктувачів у ротову порожнину та порожнину горла, зняття швів із ран, накладання, зняття та корегування гіпсової пов'язки [15 ].

Реалізація наступних видів діяльності може відбуватися у стінах лікувальних установ у звичному вигляді, відповідно до розпоряджень заступника головного лікаря з медичного обслуговування та охорони здоров'я чи відповідного компетентного немедичного персоналу і включає опитування з метою встановлення (визначення) стану пацієнта, оформлення медичної документації, виконання адміністративноорганізаторських чи службових дій, до яких належать пошук та доставка старих історій хвороб тощо. Там, де це необхідно для досягнення цілей підготовки, навчання має включати також супроводжуючі теоретичні інструктажі [18].

Тривалість роботи лікарів-інтернів визначається, виходячи 3 дотримання Закону про робочий час лікарів (Krankenanstalten-Arbeitszeitgesetzes), згідно 3 яким тривалість роботи лікарів складає 35 годин на тиждень. Особливим методом підраховується робочий час, який витрачають інтерни для участі в нічних чергуваннях, у вихідні та святкові дні. Планом підготовки інтерна визначається, що він має бути присутнім на роботі по можливості в той період, коли працюють основні служби і його наставники. 335 годин на тиждень, принаймні 25 годин мають бути виконані в період з 8-ї до 13-ї годин, інша частина може припадати на нічні чергування, вихідні та святкові дні.

3 певних обставин лікар-інтерн може працювати неповний робочий день. Щотижневий робочий час у такому випадку може бути зменшений не білыше, ніж на половину основного робочого часу. Загальна тривалість навчання за умов неповної зайнятості відповідно продовжується.

Що стосується визнання навчальних баз для підготовки фахівців вузького профілю, то ними, як правило, є підрозділи університетських клінік та клінічних інститутів, дослідницьких інститутів управління охороною здоров'я та професійних медичних центрів за виконання ними таких умов:

1) наявність спеціалізованих відділень і підрозділів супроводження (лабораторій, центрів інструментального дослідження тощо);

2) наявність висококваліфікованих спеціалістів у галузі підготовки певного фахівця, право на яку надає федеральний міністр охорони здоров'я і у справах жінок, за поданням Австрійської асоціації лікарів;

3) наявність достатньої кількості для досягнення цілей навчання необхідних технічних засобів та обладнання;

4) наявність, поряд із відомчою відповідальною особою чи керівником департаменту, незалежного фахівця з експертизи надання допомоги пацієнтам у відповідному відділенні, яке є профільним для підготовки фахівця вузького профілю;

5) відділення може бути визнаним як місце спеціалізації, якщо мінімум два лікарі, які працюють у відділенні, отримали право на ведення спеціалізації. У той же час отримати спеціалізацію у відділенні можуть лише ті лікарі, які працюють у ньому та мають на це дозвіл.

Одночасно з визнанням, навчальний центр для підготовки лікаря вузької спеціальності-крім університетсь- 
ких лікарень, клінічних інститутів та інших структурних підрозділів, включаючи будь-які підрозділи медичних університетів і дослідницьких інститутів управління охороною здоров'я - отримує певну кількість навчальних місць для навчання 3 кожної спеціальності, яка не має бути перевищеною, зважаючи на якість підготовки кожного спеціаліста. Визнання місця спеціалізації та встановлення кількості місць спеціалізації на одне відділення, які не можна перевищувати, встановлює керівник (президент) Австрійської асоціації лікарів згідно з критеріями, встановленими особами, відповідальними за організацію спеціалізації. Рішення президента можна оскаржити в Австрійській медичній асоціації, що є останньою інстанцією, яка приймає остаточне рішення.

Право установи на проведення спеціалізації чи ведення додаткових курсів можна повністю чи частково відкликати, якщо в установі для цього немає відповідних умов. Анулювання права на проведення спеціалізації здійснює президент Австрійської медичної асоціації, якщо мова іде про місце спеціалізації [17 ].

В університетських клініках, клінічних інститутах та інших структурних підрозділах, включаючи будьякі підрозділи медичних університетів і дослідницьких інститутів медичного управління, кількість стажистів може бути більшою, ніж максимальна кількість навчальних місць для навчання в основній

\section{Література}

1. Kerr J. A Comparison of Medical School Programs: University of Toronto vs.Karl Franzens Universitat, Graz, Austria / J. Kerr, A. Karrer// Medical Education. - 2003. - № 81(1). - P. 70-72.

2. Noltze A. E. Vienna Is Different/A. E. Noltze, D. Hellekes // Hospital Post Europe. -2007. - № 5. - P. 35.

3. Wayand W. Surgery in Austria / W. Wayand, W. Feil, M. Skopec // Archives of Surgery. - 2002. - № 137. - P. 217220.

4. Costigliola V. Post-graduate studies in medicine: legal regulation in the European Union. - [Електронний ресурс]. Режим доступу: $<$ http://www.emanet.org/pg-austria.cfm $>-$ Загол. з екрана. - Мова англ.

5. Spezialisierungsordnung (Rechtsgrundlage $\S 118$ Abs. 2 Z 3 ArzteG) gema $\beta$ den Beschlussen der Vollversammlung der Osterreichischen Arztekammer vom 18. Juni 2004. - [Електронний peсурс]. - Режим доступу:< http:// www.aerztekammer.at/spezialisierungen $>-$ Загол. з екрана. Мова нім.

6. Specialty selection and relative job satisfaction of family physicians and medical specialists in Austria / W. Spiegel, O. Pichlhofer, D. Haoula [et al.] // Croatian Medical Journal. 2008. -№49(3). - P. 375-383. сітці з розрахунку числа ліжок, змісту і обсягу медичних послуг, наявності відповідних кваліфікованих кадрів. Не пізніше 15 січня і 15 липня кожного року в письмовій формі, по факсу або електронною поштою до Австрійської асоціації лікарів мають бути подані списки осіб, які знаходяться на стажуванні у даному лікувальному закладі станом на 1 січня 11 липня кожного року.

Особлива увага приділяється видачі ліцензій лікарям на можливість керувати підготовкою інтернів. Це прописано у $§ 12$ “Закону про лікарів”, де зазначається, що власником ліцензії може бути тільки кваліфікований лікар, який має не менше 3-х років стажу практичної роботи в обраній галузі, відповідає іншим критеріям - зокрема комунікативної компетенції тощо. Подання на отримання ліцензії в Австрійську асоціацію лікарів здійснює власник чи керівник закладу охорони здоров'я, який також контролює виконання умов цієї ліцензії [18].

Висновки. Післядипломна підготовка лікарів в Австрії має свої особливості, що полягають у пї відірваності від медичних університетів і підпорядкуванню Австрійській асоціації лікарів. Ступеневість (лікар загальної практики, а потім лікар-спеціаліст), організаційно-методичне забезпечення, тривалість підготовки дозволяють забезпечети високий рівень знань і вмінь з майбутнього фаху.

7. Bundesrecht konsolidiert: Gesamte Rechtsvorschrift fur Arztegesetz 1998. - [Електронний ресурс]. - Режим доступу: < http://www.ris.bka.gv.at/Geltende Fassung.wxe? Abfrage $=$ Bundesnormen $\&$ Gesetzesnummer $=10011138>-$ Загол. $з$ екрана. - Мова нім.

8. Prufungsordnung der Osterreichischen Arztekammer fur die Prufung zumArzt furAllgemeinmedizin und die Facharztprufung -PO 2011.-[Електронний ресурс]. - Режим доступу: $<$ http:// www.aerztekammer.at/arztprufung/-/journal_content/ 56 I N S TANCE_ 9 I 8 m/10431/26491?_56_ INSTANCE_9I8m_backU RL=http $\% 3 \mathrm{~A} \% 2 \mathrm{~F} \% 2$ Fwww. aerztekammer.at $\% 2$ Farztprufung $>$-Загол. з екрана. - Мова нім.

9. Bundesrecht konsolidiert: Gesamte Rechtsvorschrift fur Arztegesetz 1998. - [Електронний ресурс]. - Режим доступу: $<$ http://www.ris.bka.gv.at/GeltendeFassung.wxe?Abfrage $=$ Bundesnormen $\&$ Gesetzesnummer $=10011138>-$ Загол. 3 екрана. - Мова нім.

10. Prufung zum Arzt fur Allgemeinmedizin und Facharzt. [Електронний ресурс]. - Режим доступу:< http:// www.aerztekammer.at/arztprufung $>-$ Загол. 3 екрана. Мова нім.

11. Allocation of Training Posts to Applicants for Postgraduate Medical Education in Austria: Survey and 
Analysis / W. Spiegel., D. Haoula, B. Schneider, M. Maier. // Academic Medicine. - 2004. - № 79 (7) - P. 703-710.

12. Allocation of Training Posts to Applicants for Postgraduate Medical Education in Austria: Survey and Analysis / W. Spiegel, D. Haoula, B. Schneider, M. Maier // Academic Medicine. - 2004. - № 79 (7) - P. 703-710.

13. Arzteausbildungsordnung. - [Електронний ресурс]. Режим доступу:< http://www.aerztekammer.at/arzteausbildungsordnung $>$ - Загол. з екрана. - Мова нім.

14. Specialty selection and relative job satisfaction of family physicians and medical specialists in Austria / W. Spiegel, O. Pichlhofer, D. Haoula [et al]. // Croatian Medical Journal. 2008. - №49(3). - P. 375-383.

15. Turnusarzte-Tatigkeitsprofil. - [Електронний ресурс]. - Режим доступу:< http://www.aerztekammer.at/web/ osterreichische arztekammer/ausbildungsstattenverzeichnis $>$
- Загол. $з$ екрана. - Мова нім.

16. Kerr J. A Comparison of Medical School Programs: University of Toronto vs.Karl Franzens Universitat, Graz, Austria / J. Kerr, A. Karrer // Medical Education. - 2003. - № 81(1). - P. 70-72.

17. Spezialisierungsordnung (Rechtsgrundlage $\S 118$ Abs. 2 Z 3 ArzteG) gema $\beta$ den Beschlussen der Vollversammlung der Osterreichischen Arztekammer vom 18. Juni 2004. - [Електронний ресурс]. - Режим доступу:< http:// www.aerztekammer.at/spezialisierungen $>-$ Загол. з екрана. Мова нім.

18. Bundesrecht konsolidiert: Gesamte Rechtsvorschrift fur Arztegesetz 1998. - [Електронний ресурс]. - Режим доступу: < http://www.ris.bka.gv.at/GeltendeFassung.wxe? Abfrage $=$ Bundesnormen $\&$ Gesetzesnummer $=10011138>-3 \mathrm{a}-$ гол. з екрана. - Мова нім. 